RAD Conference Proceedings, vol. 5, pp. 94-99, 2021

ISSN 2466-4626 (online) | DOI: 10.21175/RadProc.2021.18

www.rad-proceedings.org

\title{
OXIDATIVE DISSOLUTION OF NEPTUNIUM(IV) OXIDE IN CARBONATE SOLUTIONS
}

\author{
N.M. Chervyakov' ${ }^{1}$ A.V. Boyarintsev ${ }^{*}$, S.A. Perevalov ${ }^{2}$, S.I. Stepanov ${ }^{1}$, S.E. Vinokurov ${ }^{2}$ \\ ${ }^{1}$ Mendeleev University of Chemical Technology, Moscow, Russia \\ ${ }^{2}$ Vernadsky Institute of Geochemistry and Analytical Chemistry, Russian Academy of Sciences, Moscow, Russia
}

\begin{abstract}
This article presents preliminary results of the study of neptunium(IV) oxide dissolution in aqueous solutions of $\mathrm{Na}_{2} \mathrm{CO}_{3}$ in the presence of ammonium persulfate and hydrogen peroxide. In these carbonate systems, the value of $\mathrm{NpO}_{2}$ dissolution yield did not exceed 1.5-1.6\%. Ultrasonication makes it possible to significantly increase the dissolution rate of neptunium(IV) oxide in $\mathrm{Na}_{2} \mathrm{CO}_{3}$ solutions in the presence of hydrogen peroxide. Under such conditions, about $25 \%$ of neptunium(IV) oxide powder can be dissolved in one dissolution step (210-270 min). A possible factor affecting the increase of $\mathrm{NpO}_{2}$ dissolution yield is the increase of oxidative and reaction activity in the carbonate systems under ultrasonic impact.
\end{abstract}

Key words: Neptunium dioxide, oxidative dissolution, carbonate solutions, hydrogen peroxide, ammonium persulfate, ultrasonic treatment.

\section{INTRODUCTION}

Neptunium, just like other transuranium elements (TUEs) ( $\mathrm{Pu}, \mathrm{Np}, \mathrm{Am}$, and $\mathrm{Cm}$ ) is a by-products of fuel irradiation in nuclear reactors (NR). Due to their properties, TUEs have a significant influence on the nuclear fuel cycle (NFC), influencing and frequently defining requirements to procedures related to the management, of spent nuclear fuel (SNF) and highlevel radioactive waste (HLW) [1]. Of all neptunium isotopes forming during irradiation of nuclear fuel, ${ }^{237} \mathrm{~Np}$ is the longest-lived one (half-life is $2.144 \cdot 10^{6}$ years), therefore it can accumulate in sufficient quantities. In the spent nuclear fuel, neptunium can be in the form of an individual $\mathrm{NpO}_{2-x}$ oxide phase [2] However, the bulk of $\mathrm{NpO}_{2}$ usually forms a solid solution in the $\mathrm{UO}_{2}$ matrix.

One of the paths to advance NFC is to improve the SNF reprocessing technology. Therefore, continuous modernization of the existing industrial PUREX process and the development of alternative approaches, including the SNF reprocessing in carbonate and carbonate-alkaline media, will be carried out. In such approaches, oxidative dissolution of uranium oxide SNF is carried out in aqueous systems $\mathrm{M}_{2} \mathrm{CO}_{3}-\mathrm{H}_{2} \mathrm{O}_{2}$ (where $\mathrm{M}$ is $\mathrm{Na}^{+}, \mathrm{K}^{+}, \mathrm{NH}_{4}^{+}$) [3][7] or anodic dissolution of SNF in carbonate and bicarbonate media [8]-[10]. In this case, the $\mathrm{UO}_{2}$ or $\mathrm{U}_{3} \mathrm{O}_{8}$ is oxidized and dissolution in carbonate solutions in the form of soluble carbonate complexes $\left[\mathrm{UO}_{2}\left(\mathrm{CO}_{3}\right)_{2}\left(\mathrm{H}_{2} \mathrm{O}\right)_{2}\right]^{2-}$, $\left[\mathrm{UO}_{2}\left(\mathrm{CO}_{3}\right)_{3}\right]^{4-}$, and in the case of using $\mathrm{H}_{2} \mathrm{O}_{2}$ in the form of mixed peroxo-carbonate complexes $\left[\mathrm{UO}_{2}\left(\mathrm{O}_{2}\right)_{x}\left(\mathrm{CO}_{3}\right)_{y}\right]^{(2-2 x-2 y)}$ with $x=1-3$, $y=3-x[11]$.

The chemical behavior of individual oxides of neptunium(IV), plutonium(IV), and uranium(IV) differs during the oxidative dissolution process. One of the main reasons for this is the difference in the redox potential of these elements. Thus, the chemical behavior of TUEs oxides $\left(\mathrm{PuO}_{2}, \mathrm{NpO}_{2}, \mathrm{Am}_{2} \mathrm{O}_{3}, \mathrm{Cm}_{2} \mathrm{O}_{3}\right)$ during SNF reprocessing in carbonate media will depend on redox reactions taking place in carbonate or alkaline systems. To dissolve TUEs oxides in carbonate solutions, it is necessary to oxidize them to the highest degrees of oxidation which, as shown in [12], have greater solubility.

An important feature is that hydrogen peroxide $\left(\mathrm{H}_{2} \mathrm{O}_{2}\right)$ does not oxidize the $\mathrm{Pu}, \mathrm{Np}$, and Am oxides in contrast to $\mathrm{UO}_{2}$ which is oxidized to $\mathrm{UO}_{3}$ [13]. In this case, the oxide phases of the TUEs as a part of SNF should not be dissolved in carbonate solutions together with uranium in the oxidative leaching step [6,13,14]. In the case of anodic dissolution of SNF in carbonate media, $\mathrm{Np}$ (IV) in the form of $\mathrm{NpO}_{2}$ can be oxidized to a hexavalent oxidation state. For stabilization of $\mathrm{Np}(\mathrm{VI})$ in carbonate solutions, as well as its oxidation from lower oxidation states to $\mathrm{Np}(\mathrm{VI})$, the bubbling of ozone $\left(\mathrm{O}_{3}\right)$ through a layer of suspension can be used [9].

In the presence of $\mathrm{H}_{2} \mathrm{O}_{2}, \mathrm{~Np}(\mathrm{VI})$ is reduced to $\mathrm{Np}(\mathrm{V})$ in carbonate solutions [15]. As a result of the reduction of $\mathrm{Np}(\mathrm{VI})$ to $\mathrm{Np}(\mathrm{V})$, chemical processes in aqueous carbonate solutions are often defined by the redox equilibrium of the $\mathrm{NpO}_{2}{ }^{2+}-\mathrm{NpO}_{2}{ }^{+}$couple.

The addition of $\mathrm{H}_{2} \mathrm{O}_{2}$ to alkaline solutions not containing free carbonate ions leads to precipitation of neptunium [16]. Neptunium in various oxidation states in carbonate-peroxide solutions participates in redox reactions to the form of $\mathrm{Np}(\mathrm{V})$ species. Neptunium(VI) in the form of $\left[\mathrm{Np}^{\mathrm{VI}} \mathrm{O}_{2}\left(\mathrm{CO}_{3}\right)_{3}\right]^{4^{-}}$at the presence of stoichiometric amounts of $\mathrm{H}_{2} \mathrm{O}_{2}$ is reduced to $\mathrm{Np}(\mathrm{V})$, and $\mathrm{Np}(\mathrm{IV})$ is oxidized to $\mathrm{Np}(\mathrm{V})$. The carbonate

\footnotetext{
*aboyarincev@muctr.ru
} 
complex $\left[\mathrm{Np}^{\mathrm{V}} \mathrm{O}_{2}\left(\mathrm{CO}_{3}\right)_{3}\right]^{5^{-}}$is formed in both cases. When an excess of $\mathrm{H}_{2} \mathrm{O}_{2}$ is added, an amorphous brown precipitate is formed [17], which leads to a decrease in the content of neptunium in the carbonate solution.

In carbonate or bicarbonate solutions, $\mathrm{H}_{2} \mathrm{O}_{2}$ not only oxidizes or reduces neptunium but also participates in processes of formation of mixed peroxocarbonate complexes. It was established [18]-[20] that in presence of $\mathrm{H}_{2} \mathrm{O}_{2}$ in solutions of $\mathrm{NaHCO}_{3}-\mathrm{Na}_{2} \mathrm{CO}_{3}$, there occurs both oxidation of $\mathrm{Np}(\mathrm{IV})$ to $\mathrm{Np}(\mathrm{V})$ and partially to $\mathrm{Np}(\mathrm{VI})$, and formation of a mixed peroxocarbonate complex of $\mathrm{Np}$ (IV) with structure $\left[\mathrm{Np}^{\mathrm{IV}}\left(\mathrm{O}_{2}\right)\left(\mathrm{CO}_{3}\right)_{2}\right]^{2-}$. In presence of an excessive quantity of $\mathrm{H}_{2} \mathrm{O}_{2}, \mathrm{~Np}(\mathrm{~V})$ is oxidized to $\mathrm{Np}(\mathrm{VI})$, and then slowly reduces (with decomposition excess of $\mathrm{H}_{2} \mathrm{O}_{2}$ ) to $\mathrm{Np}(\mathrm{V})$. Neptunium(VI) also forms mixed peroxo-carbonate complexes with structure $\left[\mathrm{Np}^{\mathrm{VI}} \mathrm{O}_{2}\left(\mathrm{O}_{2}\right)\left(\mathrm{CO}_{3}\right)_{2}\right]^{4^{-}}$or $\left[\mathrm{Np}^{\mathrm{VI}} \mathrm{O}_{2}\left(\mathrm{O}_{2}\right)_{2} \mathrm{CO}_{3}\right]^{4^{-}}[18]-$ [20]. However, the redox equilibria in the aqueous carbonate systems will be complicated by the reactions disproportionation of $\mathrm{Np}(\mathrm{V})$, reproportionation of $\mathrm{Np}(\mathrm{IV}), \mathrm{Np}(\mathrm{VI})$, and dissociation of carbonate complexes of $\mathrm{Np}(\mathrm{V})$ [21].

In the processes of hydrochemical reprocessing of highly radioactive materials, water radiolysis occurs with the formation of $\mathrm{H}_{2} \mathrm{O}_{2}, \mathrm{O}_{2}$, and different radical products. Radicals $\mathrm{O}^{\bullet}$ and $\mathrm{OH}^{\bullet}$ formed in the radiolysis of water have extremely strong oxidizing properties, including in alkaline media. As shown in [1,22], oxidative (radiolytic) dissolution of $\mathrm{NpO}_{2}$ in aqueous solutions even without complexing agents can occur in the presence of $\mathrm{H}_{2} \mathrm{O}_{2}$. Under such conditions, the rate of radiolytic dissolution decreases in the range $\mathrm{UO}_{2}>\mathrm{NpO}_{2}>\mathrm{PuO}_{2}$. Thus, in $\mathrm{H}_{2} \mathrm{O}_{2}$-containing aqueous systems in the absence of complexing reagents, dissolution rates of $\mathrm{NpO}_{2}$ and $\mathrm{PuO}_{2}$ are lower than those of $\mathrm{UO}_{2}$. In the presence of $\mathrm{CO}_{3}{ }^{2-}$ or $\mathrm{HCO}_{3}{ }^{-}$ and in the systems where oxides occur in mixed oxide phases of solid solutions, the dissolution rates of the TUEs oxides will diverge. Fission products (FPs) and TUEs, including neptunium in SNF, are usually not only in the form of isolated phases of individual compounds integrated into the main phase of $\mathrm{UO}_{2}$ but also more in the form of solid solutions with $\mathrm{UO}_{2}$. As a result of high temperatures (up to $1700^{\circ} \mathrm{C}$ ) and extremely intense radiation fields during the NR operation, the formation of solid-phase inclusions in the fuel matrix occurs when FPs enter the $\mathrm{UO}_{2}$ structure [2].

As shown in [3], at the dissolution of $\mathrm{UO}_{2}$-based SNF (burnup of 30-45 GWd/MTU and after cooling period 27-28 years) in $\left(\mathrm{NH}_{4}\right)_{2} \mathrm{CO}_{3}-\mathrm{H}_{2} \mathrm{O}_{2}$ solutions, the extent of sample dissolution made more than $99 \%$. At the same time, the all quantity of TUEs from SNF was dissolved. Currently, data on oxidative dissolution of $\mathrm{NpO}_{2}$ in aqueous carbonate media are practically absent in the open literature sources. Therefore, additional studies are required to understand and evaluate the behavior of $\mathrm{NpO}_{2}$ in the oxidative dissolution/leaching step of SNF in carbonate media, as well as the determination of the most suitable process conditions and oxidant types.

The purpose of this research was a comparison of the chemical behavior of neptunium under conditions 95 of the oxidative dissolution of $\mathrm{NpO}_{2}$ in aqueous solutions of sodium carbonate in the presence of hydrogen peroxide and ammonium persulfate.

\section{MATERIALS AND METHODS}

The neptunium-237 dioxide in the form of a fine brown-colored powder was used in this work. Crystalline neptunium(IV) oxalate $\left(\mathrm{Np}\left(\mathrm{C}_{2} \mathrm{O}_{4}\right)_{2} \quad 6 \mathrm{H}_{2} \mathrm{O}\right)$ was obtained from a nitric acid solution of $\mathrm{Np}$ (IV) by precipitation with $15 \mathrm{wt} \%$ aqueous solutions of oxalic acid $\left(\mathrm{H}_{2} \mathrm{C}_{2} \mathrm{O}_{4}\right)$. Purified $\mathrm{Np}$ (IV) oxalate was converted to the oxide by heating in a Pt-boat at $450^{\circ} \mathrm{C}$ in a muffle furnace. All reagents used were of chemical pure grade. Doubly distilled water was used for all dilutions.

Oxidative dissolution of $\mathrm{NpO}_{2}$ powder samples with the weight of $2-5 \mathrm{mg}$ was performed in plastic test tubes. The $\mathrm{NpO}_{2}$ powder sample was weighed with an accuracy of $\pm 0.1 \mathrm{mg}$ using analytical lab balances (HR250AZG, AND, China). Phase mixing without ultrasonication was performed by magnetic stirring (MSH-30o, BioSan, Latvia) at $700 \mathrm{rpm}$. For ultrasonication, the Elmasonic xtra TT $30 \mathrm{H}$ ultrasonic bath, Elma Schmidbauer GMBH, Germany (power $(W)$ $-130 \mathrm{~W}$, frequency $(v)-37 \mathrm{kHz})$ was used.

The concentration of neptunium measurements of the solutions was made by counting aliquots that were stippled onto stainless steel disks, evaporated to dryness under a heat lamp, flamed to dull red, and counted on $\alpha$-spectrometer "Alpha Analyst" Canberra. The liquid samples before analysis were previously centrifuged on the CM-50 microcentrifuge (Elmi, Latvia) for $5 \mathrm{~min}$ at $15000 \mathrm{rpm}$.

The value of $\mathrm{NpO}_{2}$ dissolution yield $\left(A\left(\mathrm{NpO}_{2}\right)\right)$ was calculated by the following equation:

$$
A\left(\mathrm{NpO}_{2}\right)=\left(M_{\tau} / M_{\mathrm{i}}\right) \cdot 100, \%
$$

where $M_{\mathrm{i}}(\mathrm{mg})$ is the initial quantity of the $\mathrm{NpO}_{2}$ powder. The $M_{\tau}(\mathrm{mg})$ value (calculated value of the $\mathrm{NpO}_{2}$ quantity in the solution) was calculated based on the experimentally determined concentration of neptunium [Np] in the aqueous phase. The relative error for the determination of the neptunium concentration in carbonate solutions was not more than $\pm 10 \%$.

\section{RESULTS AND DISCUSSION}

The use of aqueous solutions of $\mathrm{H}_{2} \mathrm{O}_{2}$ in the $\mathrm{SNF}$ oxidative dissolution/leaching step allows the oxidation of $\mathrm{UO}_{2}$ or $\mathrm{U}_{3} \mathrm{O}_{8}$ and the production of concentrated U(VI)-containing carbonate solutions. In addition, $\mathrm{H}_{2} \mathrm{O}_{2}$ does not lead to a complication of the composition of carbonate solutions and the accumulation of salts in them, which significantly simplifies their subsequent reprocessing. Excess of $\mathrm{H}_{2} \mathrm{O}_{2}$ rapidly decomposes in the carbonate solution with the formation of oxygen and water. Ammonium persulfate can be used to oxidation of $\mathrm{Np}$ (IV) and $\mathrm{Pu}(\mathrm{IV})$ in carbonate solutions. Ammonium persulfate in carbonate solution may be added after decomposition of the excess hydrogen peroxide (typically no more than $10-15 \mathrm{~min}$ at room 
temperature and agitation). In such option of oxidative dissolution/leaching process, oxidation and dissolution of U(IV) can occur in the first step, and in the second step carry out oxidation and dissolution of $\mathrm{Np}(\mathrm{IV})$ and $\mathrm{Pu}(\mathrm{IV})$

In the absence of oxidation reagents when putting $\mathrm{NpO}_{2}$ on hold for $24 \mathrm{hrs}$ in $0.25 \mathrm{~mol} / \mathrm{L}$ solution of $\mathrm{Na}_{2} \mathrm{CO}_{3}$ with periodic agitation at room temperature $\left(20 \pm 2{ }^{\circ} \mathrm{C}\right)$ and liquid-to-solid mass ratio $(\mathrm{L} / \mathrm{S})=430 / 1$, the value of $\mathrm{NpO}_{2}$ dissolution yield was not more than $1.4 \%$ (Table 1 ).

The solubility of $\mathrm{NpO}_{2}$ depends on the particle size and crystallinity of the sample [23]. Crystalline $\mathrm{NpO}_{2}$ is almost insoluble in water (calculated solubility value, depending on conditions, is $10^{-18} \div 10^{-11} \mathrm{~mol} / \mathrm{L}$ ) [23]. Hydrated oxide of $\mathrm{Np}(\mathrm{IV}), \mathrm{NpO}_{2} \cdot x \mathrm{H}_{2} \mathrm{O}$, also has low solubility (solubility not more than $10^{-8} \mathrm{~mol} / \mathrm{L}$ ) in water and aqueous solutions containing not more than $10^{-2} \mathrm{~mol} / \mathrm{L}$ of carbonate $[24,25]$.

In the event of an increase in the concentration of carbonate ions $\left(\mathrm{CO}_{3}{ }^{2-}\right)$, the solubility of $\mathrm{NpO}_{2} \cdot x \mathrm{H}_{2} \mathrm{O}$ can increase by $1-2$ and more orders of magnitude due to the formation of mixed hydroxycarbonate complexes, whose structure can be expressed by the general formulae $\left[\mathrm{Np}^{\mathrm{IV}}(\mathrm{OH})_{x}\left(\mathrm{CO}_{3}\right)_{y}\right]^{4-x-2 y} \quad[26,27]$. With an increase in $\mathrm{CO}_{3}{ }^{2-}$ concentration, carbonate species with the structure $\left[\mathrm{Np}^{\mathrm{IV}}\left(\mathrm{CO}_{3}\right)_{4}\right]^{4^{-}}[23,28]$, $\left[\mathrm{Np}^{\mathrm{IV}}\left(\mathrm{CO}_{3}\right)_{6}\right]^{5^{-}} \quad[29]$ and $\left[\mathrm{Np}^{\mathrm{IV}}\left(\mathrm{CO}_{3}\right)_{5}\right]^{6-}[29,30]$ predominate in the carbonate solution.

The solubility of neptunium in an aqueous solution significantly depends on the state of its oxidation. In oxidative conditions, the solubility of neptunium in neutral and basic solutions increases due to the formation of more soluble species, and this effect is enhanced with temperature increase [23]-[25]. For oxidation of $\mathrm{Np}(\mathrm{IV})$ to $\mathrm{Np}(\mathrm{V})$ or $\mathrm{Np}(\mathrm{VI})$ and conversion into more soluble (in alkaline and carbonate media) species, various oxidizers can be used, for examples, such as oxygen $\left(\mathrm{O}_{2}\right)$ mixtures, $\mathrm{O}_{3}$, permanganates, persulfates, and others.

Usage of $\left(\mathrm{NH}_{4}\right)_{2} \mathrm{~S}_{2} \mathrm{O}_{8}$ as an oxidizer during the dissolution of $\mathrm{NpO}_{2}$ in the solution of $0.25 \mathrm{~mol} / \mathrm{L}$ $\mathrm{Na}_{2} \mathrm{CO}_{3}$ was ineffective. The value of $\mathrm{NpO}_{2}$ dissolution yield was not more than $1.5 \%$ when $1.0-1.5 \mathrm{~mol} / \mathrm{L}$ $\left(\mathrm{NH}_{4}\right)_{2} \mathrm{~S}_{2} \mathrm{O}_{8}$ solutions in the temperature range 20$90{ }^{\circ} \mathrm{C}$ were used (Table 1 ).

In the case when hydrogen peroxide was used, it was found that after holding a sample of $\mathrm{NpO}_{2}$ powder in $10 \mathrm{~mol} / \mathrm{L}$ solutions of $\mathrm{H}_{2} \mathrm{O}_{2}$ without agitation for $1 \mathrm{hr}$ at $\mathrm{L} / \mathrm{S}=400 / 1$ and at $20 \pm 2{ }^{\circ} \mathrm{C}$, the value of $\mathrm{NpO}_{2}$ dissolution yield was not more than $1.0 \%$ (Table 1 ). After four days of staying on hold without agitation, the $A\left(\mathrm{NpO}_{2}\right)$ value was $1.6 \pm 0.1 \%$.

The insignificant transition of neptunium to the solution can be caused by oxidation of $\mathrm{NpO}_{2}$ by the $\mathrm{O}$. and $\mathrm{OH}^{*}$ radicals as a result of radiolysis of water occurring under the influence of $\alpha$ - and $\gamma$-radiation of the ${ }^{237 \mathrm{~Np}}$ isotope.

When the addition of $\mathrm{H}_{2} \mathrm{O}_{2}(0.5 \mathrm{~mol} / \mathrm{L})$ into the suspension $\left(\mathrm{NpO}_{2}\right.$ after $24 \mathrm{hrs}$ of holding in $0.25 \mathrm{~mol} / \mathrm{L}$ solution of $\mathrm{Na}_{2} \mathrm{CO}_{3}$ with periodic agitation), the concentration of neptunium in the liquid phase decreased from $29 \mathrm{mg} / \mathrm{L}$ to $6.9 \mathrm{mg} / \mathrm{L}$ after $60 \mathrm{~min}$ of agitation. This corresponded to a decrease in the value of $A\left(\mathrm{NpO}_{2}\right)$ from $1.4 \pm 0.07 \%$ to $0.3 \pm 0.02 \%$ (Table 1 ). When agitation time was increased to $120 \mathrm{~min}$ and additional portions of the initial $10 \mathrm{~mol} / \mathrm{L}$ solutions of $\mathrm{H}_{2} \mathrm{O}_{2}$ were fed, an increase in $A\left(\mathrm{NpO}_{2}\right)$ value was not observed. After four days of staying on hold, the color of the solid phase changed from brown (characteristic for the initial sample of $\mathrm{NpO}_{2}$ ) to gray. Carbonate solution had a pale yellow color, with neptunium concentration in the solution being $9.1 \pm 0.5 \mathrm{mg} / \mathrm{L}$ $\left(A\left(\mathrm{NpO}_{2}\right)\right.$ value equal $\left.0.4 \pm 0.02 \%\right)$.

Table 1. Oxidative dissolution of $\mathrm{NpO}_{2}$ powder in aqueous solutions of $\mathrm{Na}_{2} \mathrm{CO}_{3}$, without ultrasonication. $\left[\mathrm{Na}_{2} \mathrm{CO}_{3}\right]_{\mathrm{INIT}}$ - initial concentration of $\mathrm{Na}_{2} \mathrm{CO}_{3}$ in carbonate solutions.

\begin{tabular}{|c|c|c|c|c|c|c|}
\hline Process mode & $\begin{array}{c}{\left[\mathrm{Na}_{2} \mathrm{CO}_{3}\right]_{\mathrm{INIT}},} \\
\mathrm{mol} / \mathrm{L}\end{array}$ & Oxidant & $\mathrm{L} / \mathrm{S}$ & $t,{ }^{\circ} \mathrm{C}$ & {$[\mathrm{Np}], \mathrm{mg} / \mathrm{L}$} & $A\left(\mathrm{NpO}_{2}\right), \%$ \\
\hline 24 hrs (periodic agitation) & 0.25 & - & $430 / 1$ & \multirow{5}{*}{$20 \pm 2$} & $29.0 \pm 1.4$ & $1.4 \pm 0.07$ \\
\hline $1 \mathrm{hr}$ (without agitation) & -5 & $10 \mathrm{~mol} / \mathrm{I}$ & $100 / 1$ & & $21.9 \pm 1.3$ & $1.0 \pm 0.06$ \\
\hline 4 days (without agitation) & - & 10 & $400 / 1$ & & $37.7 \pm 2.6$ & $1.6 \pm 0.1$ \\
\hline $1 \mathrm{hr}$ (agitation) & \multirow{4}{*}{0.25} & \multirow{2}{*}{$0.5 \mathrm{~mol} / \mathrm{L} \mathrm{H}_{2} \mathrm{O}_{2}$} & \multirow{2}{*}{$430 / 1$} & & $6.9 \pm 0.4$ & $0.3 \pm 0.02$ \\
\hline 4 days (without agitation) & & & & & $9.1 \pm 0.5$ & $0.4 \pm 0.02$ \\
\hline $1 \mathrm{hr}$ (agitation) & & $1.0 \mathrm{~mol} / \mathrm{L}\left(\mathrm{NH}_{4}\right)_{2} \mathrm{~S}_{2} \mathrm{O}_{8}$ & \multirow{2}{*}{$363 / 1$} & \multirow{2}{*}{$90 \pm 5$} & $37.2 \pm 2.9$ & $1.5 \pm 0.12$ \\
\hline $1 \mathrm{hr}$ (agitation) & & $1.5 \mathrm{~mol} / \mathrm{L}\left(\mathrm{NH}_{4}\right)_{2} \mathrm{~S}_{2} \mathrm{O}_{8}$ & & & $15.4 \pm 1.3$ & $0.6 \pm 0.05$ \\
\hline
\end{tabular}

The pretreated $\mathrm{NpO}_{2}$ samples obtained after four days of staying on hold in $10 \mathrm{~mol} / \mathrm{L} \mathrm{H}_{2} \mathrm{O}_{2}$ solutions without agitation were also used to study the dissolution in $0.25 \mathrm{~mol} / \mathrm{L} \mathrm{Na}_{2} \mathrm{CO}_{3}$ solutions. After $30 \mathrm{~min}$ of treatment in an ultrasonic bath (power $(W)=130 \mathrm{~W}$, frequency $(v)=37 \mathrm{kHz})$, the $A\left(\mathrm{NpO}_{2}\right)$ value was $7.2 \pm 0.3 \%$ (Table 2). With an increase in the ultrasonication time from $30 \mathrm{~min}$ to $120 \mathrm{~min}$, the $A\left(\mathrm{NpO}_{2}\right)$ value is decreased from $7.2 \pm 0.3 \%$ to $3.7 \pm 0.2 \%$ (Table 2).

Increasing $A\left(\mathrm{NpO}_{2}\right)$ value under these conditions may be due to the impact of acoustic cavitation and other ultrasonication effects. Ultrasonication allows to significantly accelerates the process of $\mathrm{U}_{3} \mathrm{O}_{8}$ oxidative dissolution in $\mathrm{Na}_{2} \mathrm{CO}_{3}$ and $\mathrm{Na}_{2} \mathrm{CO}_{3}-\mathrm{H}_{2} \mathrm{O}_{2}$ aqueous solutions, and also contributes to the obtaining of more concentrated U(VI)-containing carbonate solutions [31,32]. Acoustic flows arising when ultrasonic oscillation passes through the liquid layer in dispersed liquid media improve mixing and homogenization of the system, leading to a decrease in the thickness of the diffusion layer at the solid-liquid boundary, thus the acceleration of mass transfer. Ultrasonic cavitation impacts the solid phase, crushes it, causing destruction, renewal (cleaning), and an increase in the area of the reaction surface [33]. 
N.M. Chervyakov et al., Oxidative dissolution of neptunium(IV) oxide..., RAD Conf. Proc., vol. 5, 2021, 94-99

Table 2. Oxidative dissolution of pretreated $\mathrm{NpO}_{2}$ powder in aqueous solutions of $\mathrm{Na}_{2} \mathrm{CO}_{3}$. Conditions:

$\left[\mathrm{Na}_{2} \mathrm{CO}_{3}\right]_{\mathrm{INIT}}=0.25 \mathrm{~mol} / \mathrm{L}, 20 \pm 2{ }^{\circ} \mathrm{C}, \mathrm{L} / \mathrm{S}=400$, ultrasonication ( $W=130 \mathrm{~W}, v=37 \mathrm{kHz})$. Pretreatment mode - holding (with periodic agitation) of the $\mathrm{NpO}_{2}$ initial powder in $10 \mathrm{~mol} / \mathrm{L}$ solutions of $\mathrm{H}_{2} \mathrm{O}_{2}$ for 4 days. $\tau$ - ultrasonication time.

\begin{tabular}{|c|c|c|}
\hline$\tau, \min$ & {$[\mathrm{Np}], \mathrm{mg} / \mathrm{L}$} & $A\left(\mathrm{NpO}_{2}\right), \%$ \\
\hline 30 & $143.2 \pm 5.7$ & $7.2 \pm 0.3$ \\
\hline 60 & $79.6 \pm 4.8$ & $4.0 \pm 0.2$ \\
\hline 120 & $74.1 \pm 3.7$ & $3.7 \pm 0.2$ \\
\hline 180 & $74.1 \pm 3.7$ & $3.7 \pm 0.2$ \\
\hline
\end{tabular}

Also, during sonolysis of water (as in the case of radiolysis), there occurs the formation of $\mathrm{H}_{2} \mathrm{O}_{2}, \mathrm{O}_{2}, \mathrm{O}_{3}$, and radicals of $\mathrm{O}^{*}$ and $\mathrm{OH}^{*}$, which, despite low yield, have extremely strong oxidative properties in alkaline environments and allow to significantly accelerate redox reactions with participation of TUEs [34]. Under ultrasonication of $\mathrm{Na}_{2} \mathrm{CO}_{3}-\mathrm{H}_{2} \mathrm{O}_{2}$ containing solutions, carbonate radicals can form [35], allowing to accelerate chemical processes involving neptunium. Another positive effect of ultrasonication is to renew the surface of the $\mathrm{NpO}_{2}$ particles. In this process, the films of $\mathrm{NpO}_{2}$ oxidation products are removed (crashed). This improves the supply of oxidant to the surface of the particles $\mathrm{NpO}_{2}$ and reduces the diffusion resistance in the system. Thus, prerequisites are created for the development of the option of sonochemical dissolution of the oxides uranium, $\mathrm{NpO}_{2}$, and $\mathrm{PuO}_{2}$ in aqueous alkaline and carbonate media [36,37].

Ultrasonic treatment of $\mathrm{NpO}_{2}$ in $0.5 \mathrm{~mol} / \mathrm{L}$ solutions of $\mathrm{Na}_{2} \mathrm{CO}_{3}$ in the presence of $\mathrm{H}_{2} \mathrm{O}_{2}$, other conditions being equal, allows an increase $A\left(\mathrm{NpO}_{2}\right)$ value from $0.9 \pm 0.07 \%$ to $26.3 \pm 1.4 \%$ over $210 \mathrm{~min}$ (Table 3). However, increasing the ultrasonication time from $210 \mathrm{~min}$ to $450 \mathrm{~min}$ was leading to a step-by-step decrease in the concentration of neptunium in carbonate solution from $338.0 \pm 20.3 \mathrm{mg} / \mathrm{L}$ to $330.1 \pm 19.8 \mathrm{mg} / \mathrm{L}$ (Table 3). After $450 \mathrm{~min}$ of ultrasonication, the carbonate solution became yellowcolored. In $24 \mathrm{hrs}$, neptunium concentration in carbonate solution went down from $330.1 \pm 19.8 \mathrm{mg} / \mathrm{L}$ to $160.2 \pm 11.2 \mathrm{mg} / \mathrm{L}\left(A\left(\mathrm{NpO}_{2}\right)\right.$ equal to $\left.12.7 \pm 0.9 \%\right)$, and, at the same time, formation of yellow-colored precipitate was observed.
Thus, oxidative dissolution of $\mathrm{NpO}_{2}$ in carbonate solutions with the usage of $\mathrm{H}_{2} \mathrm{O}_{2}$ as oxidizing reagent at the current status of research did not allow reach value of $\mathrm{NpO}_{2}$ dissolution yield more than $24-26 \%$.

A decrease in the concentration of neptunium in carbonate solutions in the presence of hydrogen peroxide is associated with secondary chemical processes was occur. Under oxidizing conditions, $\mathrm{Np}(\mathrm{IV})$ is oxidized to $\mathrm{Np}(\mathrm{V})$ and the dominant carbonate and peroxo-carbonate complexes are transformed. The stability constants of carbonate species $\mathrm{Np}(\mathrm{V})$ are lower compared to $\mathrm{Np}(\mathrm{IV})$. Apparently, this also applies to the mixed peroxocarbonate species of $\mathrm{Np}(\mathrm{IV})$ and $\mathrm{Np}(\mathrm{V})$ that are formed in these systems [21]. However, the chemical properties of mixed peroxo-carbonate species of $\mathrm{Np}(\mathrm{IV}), \mathrm{Np}(\mathrm{V})$, and $\mathrm{Np}(\mathrm{VI})$ in carbonate media have not yet been sufficiently studied. In carbonate systems, processes of disproportionation and reproportionation, dissociation, and hydrolysis of carbonate and mixed peroxo-carbonate species of neptunium occur [21].

As a result of these secondary processes, less soluble forms of $\mathrm{Np}(\mathrm{V})$ are formed, which form secondary precipitates in solution and films on the surface of solid particles of $\mathrm{NpO}_{2}$. The formation of $\mathrm{Np}(\mathrm{V})$ solid phases is accompanied by a change in the color of the solid phase from brown to gray. While secondary yellow-green colored $\mathrm{Np}$ (IV) carbonate deposits formed in carbonate solutions. The formation of secondary forms of $\mathrm{Np}(\mathrm{IV})$ and $\mathrm{Np}(\mathrm{V})$ leads to an increase in the diffusion resistance in the heterogeneous system and slows down the rate of the $\mathrm{NpO}_{2}$ oxidation/dissolution process. However, the use of ultrasonic cavitation allows not only reduces the diffusion resistance but also accelerates secondary (hydrolysis) processes as a result of which secondary neptunium-containing deposits accumulate. To increase the dissolution yield of $\mathrm{NpO}_{2}$ under ultrasonication, it is necessary to develop methods for stabilizing neptunium in carbonate solutions. A detailed study of the chemistry of redox processes and chemical equilibria in carbonate systems for minor actinides, as well as the development of methods to increase the stability of minor actinides in carbonate media, is a prerequisite for creating a scientific base and substantiating the processes of SNF processing in carbonate media.

Table 3. Dissolution of $\mathrm{NpO}_{2}$ in aqueous $\mathrm{Na}_{2} \mathrm{CO}_{3}-\mathrm{H}_{2} \mathrm{O}_{2}$ solutions. Conditions: $\left[\mathrm{Na}_{2} \mathrm{CO}_{3}\right]_{\mathrm{INIT}}=0.5 \mathrm{~mol} / \mathrm{L}, 2 \mathrm{O} \pm 2{ }^{\circ} \mathrm{C}, \mathrm{L} / \mathrm{S}=500$, ultrasonication $(W=130 \mathrm{~W}, v=37 \mathrm{kHz}) . \tau$ - dissolution (agitation/ulrasonication) time; $\left[\mathrm{Na}_{2} \mathrm{CO}_{3}\right]_{\tau}-$ concentration of $\mathrm{Na}_{2} \mathrm{CO}_{3}$ in carbonate solution after $\tau \mathrm{min} ;\left[\mathrm{H}_{2} \mathrm{O}_{2}\right]_{\mathrm{INIT}}$ - initial concentration of $\mathrm{H}_{2} \mathrm{O}_{2}$ in carbonate solution (fractional feed every $60 \mathrm{~min}$ ).

\begin{tabular}{|l|c|c|c|c|c|}
\hline No & $\tau, \min$ & {$\left[\mathrm{Na}_{2} \mathrm{CO}_{3}\right]_{\tau}, \mathrm{mol} / \mathrm{L}$} & {$\left[\mathrm{H}_{2} \mathrm{O}_{2}\right]_{\mathrm{INIT}, \mathrm{mol} / \mathrm{L}}$} & {$[\mathrm{Np}], \mathrm{mg} / \mathrm{L}$} & $A\left(\mathrm{NpO}_{2}\right), \%$ \\
\hline \multicolumn{5}{|c|}{ Without ultrasonication } \\
\hline 1 & 60 & 0.38 & 2.3 & $2.6 \pm 0.23$ & $0.14 \pm 0.01$ \\
\hline 2 & 150 & 0.34 & 1.0 & $15.0 \pm 0.76$ & $0.9 \pm 0.07$ \\
\hline \multicolumn{5}{|c|}{ Ultrasonication } \\
\hline 3 & 210 & 0.34 & & $438.0 \pm 21.9$ & $26.3 \pm 1.4$ \\
\hline 4 & 270 & 0.31 & \multirow{2}{*}{1.0} & $378.1 \pm 15.1$ & $25.1 \pm 1.9$ \\
\hline 5 & 330 & 0.28 & & $338.0 \pm 20.3$ & $24.6 \pm 1.8$ \\
\hline 6 & 390 & 0.28 & & $33.7 \pm 13.9$ & $24.4 \pm 1.8$ \\
\hline 7 & 450 & 0.28 & & $160.2 \pm 11.8$ & $24.1 \pm 1.7$ \\
\hline 8 & 510 & 0.26 & & & $12.7 \pm 0.9$ \\
\hline
\end{tabular}




\section{CONCLUSION}

Preliminary results of $\mathrm{NpO}_{2}$ oxidative dissolution in solutions of $\mathrm{Na}_{2} \mathrm{CO}_{3}$ in the presence of $\mathrm{H}_{2} \mathrm{O}_{2}$ showed a possibility of partial dissolution of neptunium(IV) oxide in carbonate solutions. Ultrasonic treatment allows to significantly increase $\mathrm{NpO}_{2}$ dissolution yield in $\mathrm{Na}_{2} \mathrm{CO}_{3}-\mathrm{H}_{2} \mathrm{O}_{2}$ solutions. The maximum value of $\mathrm{NpO}_{2}$ dissolution yield equal to $26 \%$ was achieved in $210 \mathrm{~min}$ of ultrasonic treatment $(W=130 \mathrm{~W}$, $v=37 \mathrm{kHz})$ in a solution of $0.5 \mathrm{~mol} / \mathrm{L} \mathrm{Na}_{2} \mathrm{CO}_{3}$ $1.0 \mathrm{~mol} / \mathrm{L} \mathrm{H}_{2} \mathrm{O}_{2}$ at $20 \pm 2^{\circ} \mathrm{C}$.

Obtained results allow giving a preliminary estimation of the chemical behavior of neptunium in processes of $\mathrm{SNF}$ oxidative dissolution in carbonate media. At the same time, additional detailed studies of the chemistry of redox processes and chemical equilibria in carbonate systems under oxidizing conditions containing neptunium and other minor actinides are required. Determination of minor actinide chemistry in carbonate systems can serve as a scientific foundation for the justification and development of the new non-acidic alternative approaches for SNF reprocessing, in particular, to increase the efficiency of the SNF reprocessing technology and to develop processes for the separation of the neptunium and other minor actinides.

Acknowledgments: The research was supported by the Mendeleev University of Chemical Technology, project № T-2020-009.

\section{REFERENCES}

1. T. Fanghänel, J. P. Glatz, R. J. M. Konings, V. V. Rondinella, J. Somers, "Transuranium elements in the nuclear fuel cycle," in Handbook of Nuclear Engineering, D.G. Cacuci, Ed. Boston (Massachusetts), USA: Springer, 2010, vol. 5, ch. 26, pp. 2935-2998. https://doi.org/10.1007/978-0-387-98149-9

2. P. Gotcu-Freis, High temperature thermodynamic studies on the transuranium oxides and their solid solutions, Amsterdam, The Netherlands: IOS Press, 2011.

3. C. Z. Soderquist et al., "Dissolution of irradiated commercial $\mathrm{UO}_{2}$ fuels in ammonium carbonate and hydrogen peroxide," Ind. Eng. Chem. Res., vol. 50, pp. 1813-1818, 2011. https://doi.org/10.1021/ie101386n

4. S. M. Peper et al., "Kinetic study of the oxidative dissolution of $\mathrm{UO}_{2}$ in aqueous carbonate media," Ind. Eng. Chem. Res., vol. 43, pp. 8188-8193, 2004. https://doi.org/10.1021/ie049457y

5. S. C. Smith, S. M. Peper, M. Douglas, K. L. Ziegelgruber, E. C. Finn, "Dissolution of uranium oxides under alkaline oxidizing conditions," J. Radioanal. Nucl. Chem., vol. 282, no. 3, pp. 617-621, 2009.

https://doi.org/10.1007/s10967-009-0182-8

6. D. Y. Chung et al., "Oxidative leaching of uranium from SIMFUEL using $\mathrm{Na}_{2} \mathrm{CO}_{3}-\mathrm{H}_{2} \mathrm{O}_{2}$ solution," J. Radioanal. Nucl. Chem., vol. 284, pp. 123-129, 2010. https://doi.org/10.1007/s10967-009-0443-6

7. S. I. Stepanov, A. M. Chekmarev, "Concept of spent nuclear fuel reprocessing,” Dokl. Chem., vol. 423, no. 1, pp. 276-278, 2008.
https://doi.org/10.1134/So012500808110037

8. N. Asanuma et al., "Anodic dissolution of $\mathrm{UO}_{2}$ pellet containing simulated fission products in ammonium carbonate solution," J. Nucl. Sci. Tech., vol. 43, no. 3, pp. 255-262, 2006. https://doi.org/10.1080/18811248.2006.9711087

9. N. Asanuma, M. Harada, Y. Ikeda, H. Tomiyasu, "New approach to the nuclear fuel reprocessing in non-acidic aqueous solutions," J. Nucl. Sci. Technol., vol. 38, no. 10, pp. 866-871, 2001. https://doi.org/10.1080/18811248.2001.9715107

10. K. W. Kim, G. I. Park, E. H. Lee, K. W. Lee, K. C. Song, "Electrolytic dissolutions of $\mathrm{UO}_{2}$ and SIMFUEL in carbonate solutions at several pHs," Int. J. Chem. Mol. Eng., vol. 4, no. 11, pp. 707-710, 2010. https://doi.org/10.5281/zenodo.1077327

11. W. Runde, L. F. Brodnax, S. M. Peper, B. I. Scott, G. Jarvinen, "Structure and stability of peroxo complexes of uranium and plutonium in carbonate solutions," in Actinides 2005 Conf. Proc., Manchester, UK, 2005

12. M. Altmaier, X. Gaona, T. Fanghänel, "Recent advances in aqueous actinide chemistry and thermodynamics," Chem. Rev., vol. 113, no. 2, pp. 901-943, 2013. https://doi.org/10.1021/cr300379w

13. K.W. Kim et al., "A conceptual process study for recovery of uranium alone from spent nuclear fuel by using high-alkaline carbonate media," Nucl. Technol., vol. 166, no. 2, pp. 170-179, 2009.

https://doi.org/10.13182/NTo9-A7403

14. J. B. Hiskey, "Hydrogen peroxide leaching of uranium in carbonate solutions," Transactions of the Institution of Mining and Metallurgy, Section C: Mineral Processing and Extractive Metallurgy, vol. 89, pp. 145-152, 1980.

15. G. S. Goff, L. F. Brodnax, M. R. Cisneros, W. H. Runde, "Redox chemistry of actinides in peroxide-carbonate media: Applications to developing a novel process for spent nuclear fuel reprocessing," AIChE Annual Meeting, Environmental Division, Salt Lake City (Utah), USA, Nov. 4-9, 2007, 271e.

16. Z. Yoshida, S. G. Johnson, T. Kimura, J. R. Krsul, "Neptunium," in The Chemistry of the Actinide and Transactinide Elements, L. R. Morss, N. M. Edelstein, J. Fuger, Eds., Dordrecht, The Netherlands: Springer, 2006, vol. 2, ch. 6, pp. 699-812. https://doi.org/10.1007/1-4020-3598-5

17. G. D. Jarvinen, W. H. Runde, G. S. Goff, "Development of alkaline solution separation for potential partitioning of used nuclear fuels," in Proc. SESTEC-201O, Indira Gandhi Center for Atomic Research, Kalpakkam, India, 2010, manuscript no. LA-UR-09-08250.

Retrieved from:

https://www.osti.gov/servlets/purl/981842

Retrieved on: Jun. 15, 2021

18. V. P. Shilov, A. B. Yusov, A. V. Gogolev, A. M. Fedoseev, "Behavior of $\mathrm{Np}(\mathrm{VI})$ and $\mathrm{Np}(\mathrm{V})$ ions in $\mathrm{NaHCO}_{3}$ solutions containing $\mathrm{H}_{2} \mathrm{O}_{2}$," Radiochem., vol. 47, no. 6, pp. 558-562, 2005 .

https://doi.org/10.1007/s11137-006-0007-3

19. V. P. Shilov, A. M. Fedoseev, "Reaction of Np(VI) with $\mathrm{H}_{2} \mathrm{O}_{2}$ in carbonate solutions," Radiochem., vol. 52, no. 3, pp. 245-249, 2010. https://doi.org/10.1134/S1066362210030045

20. V. P. Shilov, A. M. Fedoseev, "Oxidation of Np(IV) with hydrogen peroxide in carbonate solutions," Radiochem., vol. 55, no. 3, pp. 287-290, 2013. https://doi.org/10.1134/S1066362213030077

21. V.P. Shilov, A.B. Yusov Redox reactions of actinides in carbonate and alkaline solutions, Russ. Chem. Rev., vol. 71, no. 6, pp. 465-488, 2002.

https://doi.org/10.1070/RC2002v071no6ABEHooo719 
22. С. И. Ровный, П. П. Шевцев, “Современное состояние и пути совершенствования радиохимической технологии выделения и очистки урана и плутония,” Вопросы радиационной безопасности, но. 2. стр. 5-13, 2007.

(S. I. Rovny, P. P. Shevtsev, "Modern state and ways to improve radiochemical technology for the isolation and purification of uranium and plutonium," Radiation Safety Issues, no. 2, pp. 5-13, 2007.)

23. R. J. Lemire, An assessment of the thermodynamic bahaviour of neptunium in water and model groundwaters from 25 to $150^{\circ} \mathrm{C}$, Rep. AECL-7817, Atomic Energy of Canada Limited Whiteshell Nuclear Research Establishment Pinawa, Manitoba, Canada, 1984.

Retrieved from:

https://inis.iaea.org/collection/NCLCollectionStore/ P ublic/16/041/16041385.pdf Retrieved on: Jun. 15, 2021

24. S. S. Kim, M. H. Baik, K. C. Kang, "Solubility of neptunium oxide in the KURT (KAERI Underground Research Tunnel) groundwater," J. Radioanal. Nucl. Chem., vol. 280, pp. 577-583, 2009.

https://doi.org/10.1007/s10967-009-7481-y

25. D. Rai, N. J. Hess, A. R. Felmy, D. A. Moore, M. Yui, "A thermodynamic model for the solubility of $\mathrm{NpO}_{2}(\mathrm{am})$ in the aqueous $\mathrm{K}^{+}-\mathrm{HCO}_{3}{ }^{-}-\mathrm{CO}_{3}{ }^{2-}-\mathrm{OH}^{-}-\mathrm{H}_{2} \mathrm{O}$ system," Radiochim. Acta, vol. 84, no. 3, pp. 159-169, 1999. https://doi.org/10.1524/ract.1999.84.3.159

26. T. E. Eriksen et al., Solubility of the redox-sensitive radionuclides ${ }^{99} \mathrm{Tc}$ and ${ }^{237 \mathrm{~Np}}$ under reducing conditions in neutral to alkaline solutions. Effect of carbonate, SKB Tech. Rep. 93-18, Swedish Nuclear Fuel And Waste Management Co., Stockholm, Sweden, 1993.

Retrieved from:

https://www.skb.se/publikation/9249/TR9318webb.pdf

Retrieved on: Jun. 15, 2021

27. A. Kitamura, Y. Kohara, "Solubility of neptunium(IV) in carbonate media,” J. Nucl. Sci. Tech., vol. 39, no. sup3, pp. 294-297, 2002. https://doi.org/10.1080/00223131.2002.10875466

28. A. I. Moskvin, "Complex formation of neptunium(IV, V, VI) in carbonate solutions," Sov. Radiochem., vol. 13, no. 5, pp. 694-699, 1971.

29. P. Vitorge, H. Capdevila, $N p(V)$ et $N p(V I)$ en solution aqueuse bicarbonate/carbonate, Rapport CEA-R-5793, Commissariat à l'Energie Atomique, France, 1998. (P. Vitorge, H. Capdevila, $N p(V)$ and $N p(V I)$ in bicarbonate/carbonate aqueous solutions, Report
CEA-R-5793, Atomic Energy Commission, France, 1998.)

30. A. Saito, K. Ueno, "The precipitation of some actinide element complex ions by using hexammine cobalt(III) cation-V: Absorption spectra and the precipitation of neptunium(IV), (V) and (VI) carbonate complex ions," J. Inorg. Nucl. Chem., vol. 39, no. 2, pp. 315-318, 1977. https://doi.org/10.1016/0022-1902(77)80021-3

31. S. I. Stepanov, A. V. Boyarintsev, A. M. Chekmarev, "Physicochemical foundations of spent nuclear fuel leaching in carbonate solution," Dokl. Chem., vol. 427, no. 2, pp. 202-206, 2009. https://doi.org/10.1134/So012500809080060

32. S. I. Stepanov et al., "CARBEX process, a new technology of reprocessing of spent nuclear fuel," Russ. J. Gen. Chem., vol. 81, no. 9, pp. 1949-1959, 2011. https://doi.org/10.1134/S1070363211090404

33. Б.А. Агранат, М. Н. Дубровин, Н. Н. Хавский, Г.И.Эскин, Основы физики и техники ультразвука, Москва, Высшая школа, 1987.

(B. A. Agranat, M. N. Dubrovin, N. N. Havsky, G. I. Eskin, Fundamentals of physics and ultrasound technology, Moscow, Higher School, 1987.)

34. M. V. Nikonov, V. P. Shilov, N. N. Krot, "The influence of ultrasound for redox reactions of actinide ions," in International Conference on Actinides - 89, Tashkent, USSR, 1989, INIS-SU-257.

35. А.В. Гоголев, В.П. Шилов, А.М. Федосеев, А.К. Пикаев, “Кинетика радиационно-химических реакций трех- и четырехвалентных актиноидов и лантаноидов в карбонатных растворах," Известия АН СССР. Серия химическая, № 1, с. 28-32, 1990. (A.V. Gogolev, V.P. Shilov, A.M. Fedoseev, A.K. Pikaev, "Kinetics of radiation-chemical reactions of three- and four-valent actinoids and lanthanides in carbonate solutions," Izvestiya AC USSR. Chemical series, no. 1, pp. $28-32,1990$.)

36. М. В. Никонов, К. В. Куранов, . П. Шилов, "Сонохомический метод получения нептуния(VII)," Известия АН СССР. Серия химическая, № 3, С. 717. 1988.

(M. V. Nikonov, K. V. Kuranov, V. P. Shilov, "Sonochomical method of obtaining neptunium(VII)," Izvestia of the USSR Academy of Sciences. Chemical series, no. 3, pp. 717,1988 .)

37. М. В. Никонов, В. П. Шилов, “Сонохимическое растворение $\mathrm{NpO}_{2}$ и $\mathrm{PuO}_{2}$ в водных щелочных растворах,” Радиохимия, т. 32, № 6, с. 43, 1990. (M. V. Nikonov, V. P. Shilov, "Sonochemical dissolution of $\mathrm{NpO}_{2}$ and $\mathrm{PuO}_{2}$ in aqueous alkaline solutions," Radiochemistry, vol. 32, no. 6, p. 43, 1990.) 